\title{
Preface - A Special Issue (Part-I): Mafic-Ultramafic Rocks and Alkaline-Carbonatitic Magmatism and Associated Hydrothermal Mineralization - Dedication to Piero Comin-Chiaramonti
}

\author{
Lalchand Govindram Gwalani ${ }^{1 *}$, Celso de Barros Gomes ${ }^{2 \dagger}$
}

1 Copper-Gold-Fluorite Research Project, KRC-Uni.WA, c/o Ms. Shradha L. Gwalani, Boronia 26/122 Mounts Bay Village, Mounts Bay Road PERTH WA 6000, AUSTRALIA

2 Institute of Geosciences, University of São Paulo, Rua do Lago 562, 05508-080 SÃO PAULO, BRAZIL

(c) Versita sp. z o.o.

Awarded with the degrees of a B.Sc. in Human Sciences (1961) and a Ph.D. in Petrology (1967) by the University of Trieste in Italy, Piero Comin-Chiaramonti (Figure 1) eventually spent most of his academic career in this institution, holding the positions of Assistant Professor (1967-1983) and Associated Professor (1983-1986). He was inducted as a full Professor in the Faculty of Sciences of the University of Palermo in 1986, where he remained until assigned to the Faculty of Engineering of the University of Trieste in 1993. There he initially worked as a Professor of Petrology (Faculty of Sciences) and later as a Professor of Environmental Geology and Environmental Geochemistry (Faculty of Enginnering).

It was through the efforts and innovations of Professor Comin-Chiaramonti, both in the teaching process and in the development of research facilities, that the Engineering Department of the University of Trieste has

*E-mail: Igwalani@gmail.com, http://lggwalani.jimdo.com/

†E-mail: cgomes@usp.br today attained world-wide recognition. In 2009, he was granted the award of "Eminent Scientist" by the Faculty of Engineering, and retired from active service in the following year. He is now devoting part of his time to research activites.

With his remarkable skill, greater efficiency, resolute determination and untiring efforts, Professor CominChiaramonti nursed and actively participated as a member and critical reviewer of several international scientific journals and as a consultant reviewer of some organizations such as COFIN (Co-Financial support from the Italian Ministry for University and Scientific Research), CNR (National Research Council, Italy), MIUR (Ministry of University and Research) and the Georgian National Science Foundation. We take this opportunity to assure him that we shall keep his example always before us - "duty before self" - and shall do everything possible to keep up the progress he has initiated.

Professor Comin-Chiaramonti has always been a strong proponent of international collaboration in research and the transfer of knowledge and skills in geosciences. He 

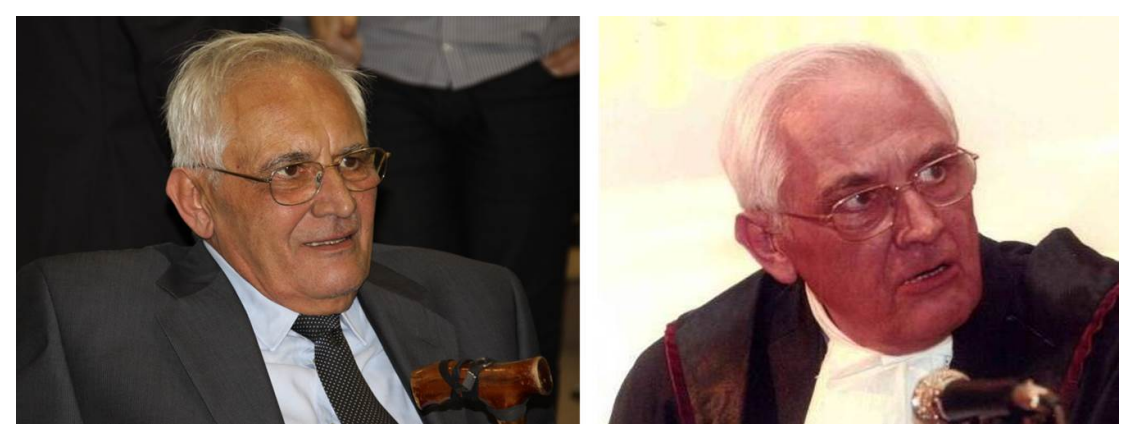

Figure 1. Professor Piero Comin-Chiaramonti.

has devoted much of his distinguished career to the dissemination of modern ideas and concepts related to petrology and geochemistry (isotope and trace-element studies). Professor Comin-Chiaramonti always enjoyed the confidence and affection of those working under him, and there can be no better tribute than this to his efficiency as an able administrator and researcher. He always dealt justly with colleagues and students and thereby inspired confidence in those working under him that honesty and hard work will never go unrewarded. Without his unstinting and enthusiastic support and close collaboration as a Guest Editor with Drs. L.G. Gwalani and Peter Downes, the work on the Special Issue of the Journal of South American Earth Sciences (vol. 41, January 2013), on "Alkaline Magmatism and Lithospheric Mantle", published in honour of Celso De Barros Gomes, may not have been completed.

Many years ago, as a student of Professor CominChiaramonti, our colleague (Co-Editor of this special issue) Maurizio Mazzucchelli of the University of Modena and Reggio Emilia (Italy) had an unforgettable experience when he was working for his Masters thesis. With great pleasure he recollects the legendary character of Comin-Chiaramonti, who was very well respected as a very demanding professor and a real friend for students and colleagues. Under his guidance Maurizio also realized the meaning of hard work and efficiency, and many other things that he never found in books. He still remembers him as the central guiding influence in research and teaching programmes, which Professor Comin-Chiaramonti carried out with great delight, enthusiasm, honesty and hard work despite suffering from some health problems.

It is said that for an honest and God-fearing man, faith is the root of the tree of Godliness. It is the most precious of gifts that the Lord can confer on a devotee.
Without faith there can be no achievement in any work. With unwavering faith in his work, Professor CominChiaramonti enduring quality and recognition which progressively influenced the students (including Maurizio) to build their career.

Whatever came to his hand he did with all his might. His sincerety of purpose made its mark wherever he was called upon to make contributions. A very important part of his research collaboration has been at the University of São Paulo in Brazil where Professor Comin-Chiaramonti mainly worked with the incredibly talented Brazilian team involving Adolpho Melfi, Celson de Barro Gomes and Vicente A.V. Girardi who are dutifully giving allegiance to make peer contributions to the understanding Brazilian geology. It is our privilege to recall his collaborative accomplishments and remarkable contributions to the better understanding of Mesozoic to Cenozoic magmatism in South America; some of these are listed below. It is our feeling, however, that these excellent achievements in research contributions and related matters, including the organization of several post-graduate courses and seminars, and the publication of collaborative scientific articles, led to great improvement in the scientific knowledge of Brazilian researchers. As a dedicated worker, he encouraged research to a degree that may not be surpassed in posterity. Thus, the recognition of his distinguished roles in the field of Brazilian geosciences speaks for his proficiency, and this was made evident by his election as a Foreign Member of the Brazilian Academy of Sciences in 2011.

Undoubtedly, Professor Comin-Chiaramonti played a long and distinguished innings to retire after placing his team in a formidable position. We pray to the Almighty for a long, happy and peaceful retirement, which he has so well earned, and which we can see in the accompanying family photo (see Figure 2. 


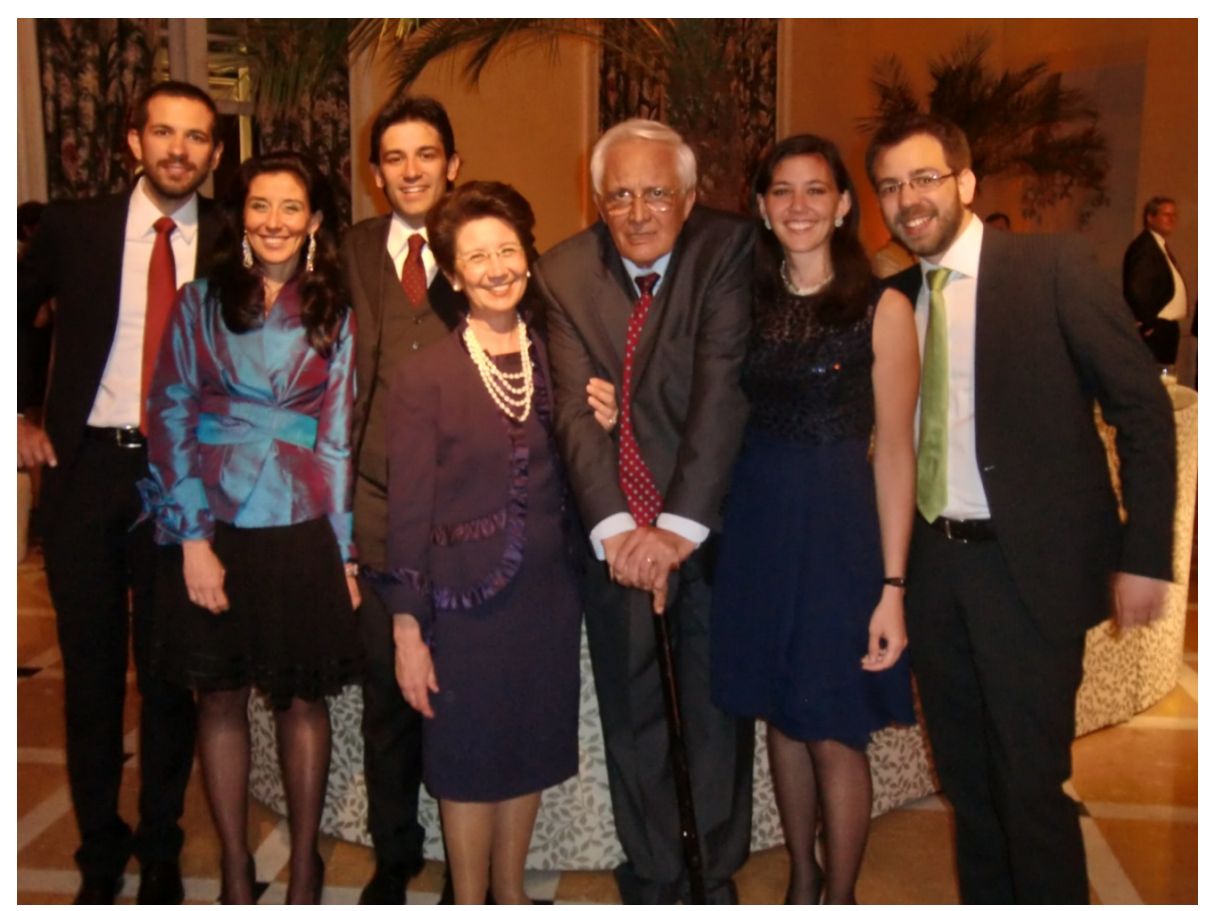

Figure 2. Piero Comin-Chiaramonti with his happy smiling family: Left to right: Lorenzo (32), Caterina (42), Alessandro (39), Paola (68), Piero (70), Maria Beatrice (27), Francesco (30)

Finaly, we would like to convey our sincere thanks to Dr. Michal Bucha, Managing Editor of this journal for providing all the help and support. Ken Rogers, Vicente A.V. Girardi, Maurizio Mazzucchelli and Kirtikumar Randive are thanked for accepting the proposal for working as Guest Editors and for cooperating in a marvellous way. We are also indebted to the authors for their contributions, to the referees for reviewing the papers and Michael Cooke for devoting his precious time in helping with the English language scrutiny of the manuscripts. LGG's daughter, Shradha Gwalani, not only patiently endured long hours of her precious time, has been his (LGG) important partner, friend and collaborator in the preparation of the CEJG special issue. LGG also feels he owed a debt of gratitude to his teacher, Shri G.S. Dhillon for his encouraging words that have enabled him to actively pursue research and related activities.

Listed below are references to some of Professor CominChiaramonti's interesting publications (research papers and books), which he published with his students and collaborators:

- Comin-Chiaramonti P., Frangipane M., The amphyclasite of Brat (Tromøy, southern Norway), Mineralogy and Petrology, 21, 1974, 280-290
- Comin-Chiaramonti P., Meriani S., Mosca R., Sinigoi S., On the occurrence of analcime in the north-eastern Azerbaijan volcanics (north-western Iran), Lithos, 12, 1979, 187-198

- Comin-Chiaramonti P., DeMarchi G., Girardi V.A.V., Sinigoi S., Evidence of mantle metasomatism and heterogeneity from peridotite inclusions of northeastern Brazil and Paraguay, EPSL, 77, 1986, 203-217

- Comin-Chiaramonti P., Civetta L., Piccirillo E.M., Bellieni G., Bittschene P., DeMarchi G., Gomes C.B., Censi P., Petrini R., Castillo A.M.C. \& Velá zquez J.C., Tertiary nephelinitic magmatism in Eastern Paraguay: petrology, $\mathrm{Sr}-\mathrm{Nd}$ isotopes and genetic relationships with associated spinelperidotite xenoliths, Europ. Journ.Mineral., 3, 1991, 507-525

- Comin-Chiaramonti P., Cundari A., Gomes C.B., Piccirillo E.M., Censi P., DeMin A., Bellieni G., Velá zquez V.F. \& Oruè, D., Potassic dyke swarm in the Sapucai graben, Eastern Paraguay: petrographical, mineralogical and geochemical outlines, Lithos, 28, 1992, 283-301 
- Comin-Chiaramonti P., Cundari A., Gomes C.B., Piccirillo E.M., Censi P., DeMin A., Bellieni G., Velá zquez V.F. \& Oruè, D., Potassic dyke swarm in the Sapucai graben, Eastern Paraguay: petrographical, mineralogical and geochemical outlines, Lithos, 28, 1992, 283-301

- Comin-Chiaramonti P., Gomes C.B. (eds.), Alkaline magmatism in the central-eastern Paraguay. Relationships with coeval magmatism in Brazil. EDUSP-FAPESP, Saão Paulo-Brazil, 1996, 464

- Comin-Chiaramonti P., Cundari A., Piccirillo E.M., Gomes C.B., Castorina F., Censi P., DeMin A., Marzoli A., Petrini R., Speziale S., Potassic and sodic igneous rocks from Eastern Paraguay: their origin from the lithospheric mantle and genetic relationships with the associated Paraná flood tholeiites, Journal of Petrology, 34, 1997, 495-528

- Comin-Chiaramonti P., Cundari A., Piccirillo E.M., Gomes C.B., Castorina F., Censi P., DeMin A., Marzoli A., Petrini R., Speziale S., Potassic and sodic igneous rocks from Eastern Paraguay: their origin from the lithospheric mantle and genetic relationships with the associated Paraná flood tholeiites, Journal of Petrology, 34, 1997, 495-528

- Comin-Chiaramonti P., Gomes C.B., Ruberti E., Antonimi A., Castorina F., Censi P., Mato Preto alkaline-carbonatite complex: geochemistry and isotope $(\mathrm{O}-\mathrm{C}, \mathrm{Sr}-\mathrm{Nd})$ constraints, Geochim. Brasiliensis, 15, 2002, 23-34
- Comin-Chiaramonti P. Gomes C.B. eds., Mesozoic to Cenozoic alkaline magmatism in the brazilian platform, EDUSP-FAPESP-SÃO PAULO-Brazil, 2005, 752

- Comin-Chiaramonti P., Lucassen F., Girardi V.A.V., De Min A., Gomes C.B., Lavas and their mantle xenoliths from intracratonic Eastern Paraguay (South American Platform) and Andean Domain, NW-Argentina: a comparative review, Mineralogy and Petrology, 98, 2009, 143-165

- Comin-Chiaramonti P., Cundari A., Ruberti E., Demin A., Gittins J., Gomes C.B. and Giwalani L.G. Genesis of analcime and nepheline-potassium feldspar-kalsilite intergrowths: a review. In: Armienti P., D'orazio M. and Rocchi S. (Eds.). Volume dedicated to Prof. Fabrizio Innocenti, Acta Vulcanologica, 21, 2009, 81-90

- Comin-Chiaramonti P., Girardi V.A.V, De Min A., Boggiani P.C., Correia C.T., Iron-rich formations at the Cerro Manomó region, Southeastern Bolivia: remnant of a BIF? Episodes, 34, 3, 2011, 177-185

- Comin-Chiaramonti P., De Min A., Girardi, Vicente A.V., Gomes C.B., Carbonatites and primary carbonates in the Rio Apa and Amambay regions, NE Paraguay. Lithos, 2013, (Available online 31 October 2013) 